\title{
Plasma leptin levels in rats with induced Toxoplasma gondii infection
}

\author{
Baltaci AK, Mogulkoc R \\ Department of Physiology, Selcuklu Medical School, Selcuk University, 42080 Konya, Turkey. \\ baltaci@selcuk.edu.tr
}

\begin{abstract}
Background: To explore the changes in plasma leptin levels of rats with induced Toxoplasma gondii infection. Methods: The study was conducted on 20 Spraque-Dawley type adult male rats, which were equally divided into two groups. Group 1, general control group. Group 2, infection group (rats in this group were infected with live Toxoplasma gondii parasite, which was injected in $0.5 \mathrm{ml}$ serum physiologic through intraperitoneal route, so that 10-12 parasites were seen in the area under a light microscope). Blood samples collected from all animals 4 weeks after the infection were analyzed to determine plasma leptin levels (RIA).

Results: There was no significant difference between the body weights of groups 1 and 2 at the end of the study. Plasma leptin levels in the infection group (group 2) were significantly higher than those in group $1(p<0.01)$. Conclusion: Toxoplasma gondii infection can cause an increase in leptin secretion without changing body weight in a period of 4 weeks in rats (Tab. 1, Ref. 25). Full Text in PDF www.elis.sk.

Key words: Toxoplasma gondii, leptin, rat.
\end{abstract}

Leptin is the 167-amino acid hormonal protein product of the obesity gene, which has been widely researched after being defined by Zhang et al (1). Leptin, which was initially described in relation to satiety and energy balance, was then claimed to be an anti-obesity factor acting through a feedback effect from adipocytes to hypothalamus. There has been a growing body of evidence emphasizing leptin as a critical hormone in the regulation of body weight and food intake in both animals and humans (2-5). Results of research also suggest that leptin is involved in metabolic regulation $(6,7)$, sexual maturation $(8,9)$, reproduction (10), hematopoiesis (11), gastrointestinal functions (12), sympathetic activation (13) and angiogenesis (14).

Leptin may be classified as a cytokine due to the similarity between the structure of leptin and its receptors and cytokines (15). Leptin structurally resembles IL-2 in particular and is a crucial T-cell growth factor (15). Circulating concentration of leptin is proportionate to the size of fat mass (16). Decrease in body weight or undernourishment results in hypoleptinemia (16), while decreased leptin secretion leads to an increase in immune defects and infections (17). Reports of the studies exploring the relation between leptin and the immune system put forward the hypothesis that low concentrations of serum leptin increase predisposition to infections by reducing T-helper (Th) cells and directly affecting thymic functions $(17,18)$. Presence of leptin receptors in $\mathrm{CD}_{4}^{+}$and $\mathrm{CD}_{8}^{+} \mathrm{T}$ lymphocytes also substantiates the correlation between leptin and immune functions.

Department of Physiology, Selcuklu Medical School, Selcuk University, 42080 Konya, Turkey

Address for correspondence: A.K. Baltaci, MD, Dept of Physiology, Selcuklu Medical School, Selcuk University, 42031, Konya, Turkey.
Leptin has a stimulating effect on Th1 cells and an inhibiting effect on Th2 cells. In the context of the cellular immune response to infections, leptin plays an important role in Th1 cell activation and the elevated levels of IL-2, IFN-y and TNF- $\alpha$, which are products of Th1. It exercises a strong stimulating effect on cytokine production of Th1. The fact that NK cell activation responds to leptin stimulation indicates that leptin also has a major part in NK cell activation $(19,20)$.

Cellular immunity is the main control mechanism in T. gondii infections. It has been revealed that T-cells mediate the major resistance mechanism against this parasite in laboratory animals and humans (21). As the immunological role of $\mathrm{T}_{8}$-lymphocyte cell functions has not been fully understood in parasitic infections, studies have concentrated more on the protective functions of $\mathrm{T}_{4}$-cells (22). Until recently, it has been accepted that $\mathrm{T}_{4}$-lymphocytes are the principal T-cells that most effectively produced both immunopathological and protective responses, while $\mathrm{T}_{8}$-lymphocytes basically act as regulators $(21,22)$. However, recent studies have demonstrated the importance of $\mathrm{T}_{8}$-cell functions in immunity against $\mathrm{T}$. gondii. The current conviction is that $\mathrm{T}_{4}$-lymphocytes assume an initial, protective role against $\mathrm{T}$. gondii, whereas $\mathrm{T}_{8}$-cells have a more critical function in actual cellular defence $(21,22)$. The objective of the present study is to explore the changes in plasma leptin levels of rats with induced toxoplasma gondii infection.

\section{Methods}

The study was conducted at S.U. Experimental Medicine Research and Application Centre on the rats obtained thereof. The study included a total of 20 6-month-old Spraque-Dawley adult male rats, which were grouped as follows: 
Group 1, (n: 10) Normal Control Group: The group not subjected to any procedure and on a normal diet.

Group 2, (n: 10) Infected Control Group: The group infected with toxoplasma gondii parasite and on a normal diet.

Experimental animals (except for those in the normal control group) were infected with live toxoplasma gondii parasite, which was obtained from Ankara University School of Medicine Parasitology Department Laboratory and which was injected in $0.5 \mathrm{ml}$ serum physiologic through intraperitoneal route, so that 10-12 parasites were seen in the area under a light microscope. Four weeks after the infection, blood samples were collected from the animals by decapitation and analyzed to determine plasma leptin levels.

\section{Plasma leptin determination}

Serum leptin analysis was carried out using Rat Leptin RIA test kit (Linco trademark catalogue no: RL-83K). Limit sensitivity of the rat leptin analysis is $0.5 \mathrm{ng} / \mathrm{ml}$ and limit linearity is 50 $\mathrm{ng} / \mathrm{ml}$. The results were expressed as $\mathrm{ng} / \mathrm{ml}$.

\section{Statistical analyses}

SPSS 13.0 statistics software was used in the calculation of data. Paired Samples t test was employed in the evaluation within the group and Student $t$ test in the evaluations between groups.

\section{Results}

No significant difference was found between groups 1 and 2 in terms of body weight at the end of the study. Plasma leptin levels in the infection group (group 2) were significantly higher than those in group $1(\mathrm{p}<0.01)$ (Tab. 1).

\section{Discussion}

There was no significant difference between body weights of groups 1 and 2 at the end of the study. Plasma leptin levels of the infection group (group 2) were significantly higher, when compared to the levels in group 1. Leptin is sometimes classified as a cytokine due to the similarity between the structure of leptin and its receptors, and cytokines (15). The structure of leptin resembles those of interleukin (IL) 6 and IL-11, while leptin receptor is homologous to IL-6 receptor (15). Besides having a stimulating effect on leukocyte synthesis, leptin has been shown to reinforce the stimulating effect of erythropoietin on erythrocytes. Therefore, leptin deficiency causes problems in haematopoiesis (23). Like bacterial antigens, leptin activates macrophages, increases their phagocytic activity and stimulates the secretion of pro-inflammatory and anti-inflammatory cytokines from the macrophages (11). Leptin accelerates neovascularisation and wound healing. Furthermore, leptin deficiency increases predisposition to infection and inflammation, and this increase is associated with an impairment of cytokine production (19). Leptin is known to have a substantial part in natural and acquired immunity. As leptin levels are elevated during infection/ inflammation, it has been argued that leptin is a crucial factor in the host's response to inflammation (24). Anorexia, which is seen in the course of infections, is believed to be the host's acute phase re-
Tab. 1. Body weights and plasma leptin levels of experimental animals.

\begin{tabular}{lccc}
\hline Groups & $\begin{array}{c}\text { Body weight } \\
\text { before study }(\mathrm{g})\end{array}$ & $\begin{array}{c}\text { Body weight } \\
\text { after study }(\mathrm{g})\end{array}$ & Leptin $(\mathrm{ng} / \mathrm{ml})$ \\
\hline Control & $266.00 \pm 32.81$ & $270.50 \pm 33.70$ & $4.09 \pm 1.15 \mathrm{~B}$ \\
Infected & $263.50 \pm 44.16$ & $269.50 \pm 42.78$ & $7.53 \pm 1.55 \mathrm{~A}$ \\
$\mathrm{P}$ & & & 0.01 \\
\hline * Means with different superscripted letters in the same column are statistically \\
significant $(\mathrm{p}<0.1)$.
\end{tabular}

sponse to infection. However, although anorexia has its uses in the onset, extended anorexia is known to exercise some harmful effects by delaying healing (25). Bacterial cell wall components (like lipopolysaccharides and peptidoglycanes), microbial nucleic acids and viral glycoproteins trigger acute phase reaction, and thus anorexia (25). Bacterial/viral products stimulate the production of proinflammatory cytokines (ILs, tumour necrosis factor alpha, TNF- $\alpha$, interferons) (19). Cytokines, in turn, increase leptin expression in adipose tissue. Both microbial products and the resulting cytokines, as well as leptin, reduce food intake. Therefore, it is speculated that TNF- $\alpha$, IL- 1 and IL- 6 are responsible for the anorexia that develops during inflammation and infection and that leptin partially mediates these effects of cytokines (20). Altogether, these data suggest that there is an inevitable relation between cellular immunity and leptin. Elevated leptin levels were established in rats with induced T. gondii infection and may be seen as an expected result. Examination of how various cytokines are affected leptin and T. gondii infection may provide us with new data on this topic.

\section{Conclusion}

Toxoplasma gondii infection can cause an increase in leptin secretion without changing the body weight within a period of 4 week in rats.

\section{References}

1. Zhang Y, Proenca R, Maffei M, Barone M, Leopold L, Friedman JM. Positional cloning of the mouse obese gene and its human homologue. Nature 1994; 372 (6505): 425-432.

2. Pelleymounter MA, Cullen MJ, Baker MB, Hecht R, Winters D, Boone T, Collins F. Effects of the obese gene-product on body weight regulation in ob/ob mice. Science 1995; 269 (5223): 540-543.

3. Considine RV, Sinha MK, Heiman ML,Kriauciunas A, Stephens TW, Nyce MR, Ohannesian JP, Marco CC, McKee LJ, Bauer TL. Serum immunoreactive-Leptin concentrations in normal-weight and obese humans. N Engl J Med 1996; 334 (5): 292-295.

4. Mercer JG, Moar KM, Rayner DV, Trayhurn P, Hoggard N. Regulation of Leptin receptor and NPY gene expression in hypothalamus of Leptin-treated obese (ob/ob) and cold exposed lean mice. FEBS Letters 1997; 402 (2-3): 185-188.

5. Trayhurn P, Hoggard N, Mercer JG, Rayner DV. Leptin: fundamentel aspects. Int J Obes Relat Metab Disord 1999; 23 (Suppl 1): 22-28.

6. Emilsson V, Liu YL, Cawthorne MA, Morton NM, Davenport M. Expression of the functional leptin receptor mRNA in pancreatic isletsand direct inhibitory action of leptin on insulin secretion. Diabetes 1997; 46 (2): 313-316. 
7. Kamohara S, Burcelin R, Halaas JL, Friedman JM, Charron MJ. Acute stimulation of glucose metabolism in mice by leptin treatment. Nature 1997; 389 (6649): 374-377.

8. Mantzoros CS, Flier JS, Rogol AD. A longitudinal assesment of hormonal and physical alterations during normal puberty in boys: rising leptin levels may signal the onset of puberty. J Clin Endocrinol Metab 1997; 82 (4): 1066-1070.

9. Matkovic V, Ilich JZ, Skugor M, Badenhop NE, Goel P, Clairmont A, Klisovic D, Nahhas RW, Landoll JD. Leptin is inversely related to age at menarche in human females. J Clin Endocrinol Metab 1997; 82 (10): 3239-3245.

10. Chehab F, Lim M, Lu R. Correction of sterility defect in homozygous obese female mice treated with human recombinant leptin. Nat Genet 1996; 12 (3): 318-320.

11. Gainsford T, Willson TA, Metcalf D, Handman E, McFarlane C, Ng A, Nicola NA, Alexander WS, Hilton DJ. Leptin can induce proliferation, differantiation and functional activation of hemopoietic cells. Proc Natl Acad Sci USA 1996; 93 (25): 14564-14568.

12. Bado A, Levasseur S, Attoub S, Kermorgant S, Laigneau JP, Bortoluzzi MN, Moizo L, Lehy T, Guerre-Millo M, Le Marchand-Brustel Y, Lewin MJ. The stomach is a source of leptin. Nature 1998; 394 (6695): 790-793.

13. Collins S, Kuhn CM, Petro AE, Swick AG, Chrunyk BA, Surwit RS. Role of leptin in fat regulation. Nature 1996; 380 (6576): 677.

14. Sierra-Honigmann MR, Nath AK, Murakami C, Garcia-Cardena G, Papapetropoulos A, Sessa WC, Madge LA, Schechner JS, Schwabb MB, Polverini PJ, Flores-Riveros JR. Biological action of leptin as an angiogenic factor. Science 1998; 281 (5383): 1683-1686.

15. Matarese G. Leptin and the immune system: how nutritional status influences the immune response. Eur Cytokine Netw 2000; 11 (1): 7-14.
16. Friedman JM, Halaas JL. Leptin and the regulation of body weight in mammals. Nature 1998; 395 (6704): 763-770.

17. Lord GM, Matarese G, Howard JK, Baker RJ, Bloom SR, Lechler RI. Leptin modulates the T-cell immune response and reverses starvationinduced immunosuppression. Nature 1998; 394 (6696): 897-901.

18. Howard JK, Lord GM, Matarese G, Vendetti S, Ghatei MA, Ritter MA, lechler RI, Bloom SR. Leptin protects mice from starvation-induced lymphoid atrophy and increases thymic cellularity in ob/ob mice. J Clin Invest 1999; 104 (8): 1051-1059.

19. Faggioni R, Feingold KR, Grunfeld C. Leptin regulation of the immune response and the immunodeficiency of malnutrition. FASEB J 2001; 15 (14): 2565-2571

20. Maruna P, Gurlich R, Frasko R. Leptin--a new acute phase reactant. Vnitr Lek 2001; 47 (7): 478-483.

21. Hakim FT, Gazzinelli RT, Denkers E, Hieny S, Shearer GM, Sher A. $\mathrm{CD}^{+} \mathrm{T}$ cells from mice vaccinated againts Toxoplasma gondii are cytotoxic for parasite infected or antigen pulsed host cells. J Immunol 1991; 147 (7): 2310-2316.

22. Gazzinelli RT, Oswald IP, James SL, Sher A. IL-10 inhibits parasite killing and nitrogen oxide production by IFN-gamma-activated macrophages. J Immunol 1992; 148 (6): 1792-1796.

23. Bennett BD, Solar GP, Yuan JQ, Mathias J, Thomas GR, Matthews W. A role for leptin and its cognate receptor in hematopoiesis. Curr Biol 1996; 6 (9): 1170-1180.

24. Ziylan YZ, Baltaci AK, Mogulkoc R. Leptin transport in the central nervous system. Cell Biochem Funct 2009; 27 (2): 63-70.

25. Cakir B, Bozkurt A, Ercan F, Yegen BC. The anti-inflammatory effect of leptin on experimental colitis: involvement of endogenous glucocorticoids. Peptides 2004; 25 (1): 95-104.

Received February 16, 2011. Accepted December 18, 2011. 